\title{
PENCUCIAN MATERIAL MAGNETIK PASIR BESI LANSILOWO MENGGUNAKAN LARUTAN ASAM KLORIDA
}

\section{THE WASHING OF MAGNETIC MATERIAL OF LANSILOWO IRON SAND USING CHLORIDE ACID SOLUTION}

\author{
${ }^{* 1}$ Ricka Prasdiantika \\ Fakultas Teknik Universitas Pandanaran Semarang, Indonesia \\ ${ }^{2}$ Susanto \\ Jurusan Teknik Kimia Politeknik Negeri Malang, Indonesia \\ Submitted: 06-03-2019; Revised: 19-10-2019; Accepted: 19-10-2019
}

\begin{abstract}
Iron sand was widely used in various fields such as in the manufacturing of magnets, cement, and steel. Iron sand has the main composition of iron oxide and several impurities of oxides. To remove these impurities, iron sand needs to be washed with acidic solution such as $\mathrm{HCl}$ solution. This study aims to minimize impurities in the magnetic material of Lansilowo iron sand. Iron sand was prepared using an external magnet to obtain magnetic material. The magnetic material was washed using distilled water and $0.5 \mathrm{M} \mathrm{HCl}$ solution. The drying process was carried out at $80^{\circ} \mathrm{C}$ for 24 hours. Magnetic material was crushed, weighed, and characterized. Material characterization was carried out using X-Ray Fluorescence (XRF), Fourier Transform Infrared (FT-IR) Spectrophotometer, and $X$-Ray Diffractometer (XRD). The Characterization results showed that washing of magnetic material using $\mathrm{H}_{2} \mathrm{O}-\mathrm{HCl} 0.5 \mathrm{M}$ was able to increase the percentage of Fe element composition in Lansilowo iron sand. The iron oxide contained in Lansilowo Iron Sand remains magnetite. The washing the iron sand magnetic material using $0.5 \mathrm{M} \mathrm{HCl}$ solution succeeded in removing impurities such as $\mathrm{Mg}, \mathrm{Pr}, \mathrm{K}, \mathrm{Cl}, \mathrm{P}, \mathrm{S}, \mathrm{Co}, \mathrm{Ce}$, and Sn as well as reducing the percentage of the Si and Al elements. The washing magnetic material using $0.5 \mathrm{M} \mathrm{H}_{2} \mathrm{O}-\mathrm{HCl}$ produced higher XRD intensities than those washed with $\mathrm{H}_{2} \mathrm{O}$. The washing magnetic material with $0.5 \mathrm{M} \mathrm{H}_{2} \mathrm{O}-\mathrm{HCl}$ was result particle size of $37,70 \pm 4,62 \mathrm{~nm}$ and crystallinity of $53.12 \%$.
\end{abstract}

Keywords: Iron Sand; Magnetic Material; Solution of Chloride Acid;Washing.

\begin{abstract}
ABSTRAK
Pasir besi banyak dimanfaatkan dalam berbagai bidang seperti pada industri pembuatan magnet, semen, dan baja. Pasir besi memiliki kandungan oksida besi dan beberapa oksida pengotor. Untuk menghilangkan oksida-oksida pengotor tersebut, pasir besi perlu dicuci dengan larutan asam seperti larutan $\mathrm{HCl}$. Penelitian ini bertujuan untuk meminimalisir oksida-oksida pengotor pada material magnetik pasir besi Lansilowo. Pasir besi dipreparasi menggunakan magnet eksternal untuk mendapatkan material magnetik. Material magnetik dicuci menggunakan akuades dan larutan $\mathrm{HCl} 0,5$ M. Proses pengeringan dilakukan pada suhu $80^{\circ} \mathrm{C}$ selama 24 jam. Material magnetik digerus, ditimbang, dan dikarakterisasi. Karakterisasi material dilakukan menggunakan X-Ray Fluorescence (XRF), Fourier
\end{abstract}

${ }^{*}$ Corresponding author: ricka.prasdiantika@unpand.ac.id

Copyright @ 2020 THE AUTHOR(S).This article is distributed under a Creative Commons Attribution-Share Alike 4.0 International license. Jurnal Teknosains is published by the Graduate School of Universitas Gadjah Mada. 
Transform Infrared (FT-IR) Spectrophotometer dan $X$-Ray Difraktometer (XRD). Hasil karakterisasi menunjukkan bahwa pencucian material magnetik dengan menggunakan $\mathrm{H}_{2} \mathrm{O}-\mathrm{HCl} 0,5$ $\mathrm{M}$ mampu meningkatkan persentase komposisi unsur Fe material magnetik pasir besi Lansilowo. Oksida besi yang terkandung dalam Pasir Besi Lansilowo tetap magnetit. Pencucian material magnetik pasir besi menggunakan larutan $\mathrm{HCl}$ 0,5 $\mathrm{M}$ berhasil menghilangkan unsur-unsur pengotor seperti $\mathrm{Mg}, \mathrm{Pr}, \mathrm{K}, \mathrm{Cl}, \mathrm{P}, \mathrm{S}, \mathrm{Co}, \mathrm{Ce}$, dan Sn serta menurukan persentase komposisi dari unsur Si dan Al. Pencucian material magnetik menggunakan $\mathrm{H}_{2} \mathrm{O}-\mathrm{HCl} \quad 0,5 \mathrm{M}$ menghasilkan intensitas XRD yang lebih tinggi dibandingkan yang dicuci dengan $\mathrm{H}_{2} \mathrm{O}$. Pencucian material magnetik dengan $\mathrm{H}_{2} \mathrm{O}-\mathrm{HCl} 0,5 \mathrm{M}$ menghasilkan ukuran partikel $37,70 \pm 4,62 \mathrm{~nm}$ dan kristalinitas sebesar $53,12 \%$.

Kata kunci: Larutan Asam Klorid; Material Magnetik; Pasir Besi; Pencucian.

\section{PENGANTAR}

Indonesia memiliki sumber daya alam mineral yang tersebar di berbagai daerah dengan jumlah yang cukup besar seperti batu bara, tanah lempung, pasir besi dan lainlain (Pari, 2000; Yulianto, 2007; Wijaya dkk., 2010). Pasir besi di Indonesia cukup banyak dimanfaatkan dalam bentuk bahan mentah sebagai bahan tambahan dalam industri semen dan pembuatan baja (Amal, 2008; Lutfi, 2012). Pasir besi di Indonesia banyak ditemukan di pesisir pantai seperti pesisir selatan pantai Lampung Barat, pantai Sunur kota Pariaman, pesisir pantai selatan Pandeglang Banten, pesisir pantai Jawa Tengah (Afza, 2011), pantai Masang Sumatera Barat (Mufit dkk., 2013), pantai selatan Kebumen Kutoarjo (Ansori, 2013), dan pantai Utara Pulau Jawa (Rahmawati dan Handayani, 2013).

Pasir besi memiliki kandungan utama oksida besi seperti maghemit $\left(\gamma-\mathrm{Fe}_{2} \mathrm{O}_{3}\right)$, hematit $\left(\mathrm{a}-\mathrm{Fe}_{2} \mathrm{O}_{3}\right.$ ), dan magnetit $\left(\mathrm{Fe}_{3} \mathrm{O}_{4}\right)$, (Cornell dan Schwertmann, 2003), senyawaan oksida lain seperti $\mathrm{Al}_{2} \mathrm{O}_{3}, \mathrm{MgO}$, dan $\mathrm{SiO}_{2}$ (Komatina dan Gudenau, 2004). Oksida besi yang terkandung pada pasir besi Lansilowo didominasi oleh oksida besi magnetit $\left(\mathrm{Fe}_{3} \mathrm{O}_{4}\right)$ (Prasdiantika dan Susanto, 2016).
Bijih besi dalam endapan pasir besi memiliki komposisi dengan kadar yang bervariasi di setiap wilayah. Komposisi bijih pasir besi yang berasal dari Karnataka, India terdiri dari unsur Fe sebanyak 63,84\%, $\mathrm{SiO}_{2}$ $2,64 \%, \mathrm{Al}_{2} \mathrm{O}_{3} 3,98 \%$, $\mathrm{CaO} 0,14 \%$, dan $\mathrm{MgO} 0.08 \%$ (Kumari dkk., 2010). Pasir besi dari daerah Sukabumi Jawa Barat memiliki komposisi kimia yaitu Fe 76,93\%, Ti 21,02\%, Mn 0,91\%, Zn 0,08\%, Nb 0,03\%, V 0,36\%, Sn 0,07\% dan Sb 0,14\% (Setiawati dkk., 2013). Hasil karakterisasi material magnetik pasir besi Lansilowo mengandung unsur Fe sebanyak 46,13\%, unsur Cr sebanyak 28,08\%, Mg sebanyak 10,11\%, Si sebanyak $8,20 \%$, dan unsur-unsur minor lainnya (Prasdiantika dan Susanto, 2016).

Yulianto (2007) melakukan preparasi material magnetik pasir besi di laboratorium secara manual menggunakan magnet eksternal. Namun bijih besi yang didapatkan masih bercampur dengan tanah liat, sehingga dibutuhkan suatu cara untuk memurnikan pasir besi tersebut.

Oleh karena itu, untuk mendapatkan material magnetik pasir besi dengan kemurnian yang tinggi, material magnetik perlu dicuci dengan akuades untuk menghilangkan pengotor seperti tanah, jasad renik, dan sampah dedaunan.

Material magnetik yang dipreparasi dengan menggunakan magnet eksternal dan pencucian dengan akuades masih mengandung beberapa oksida pengotor seperti oksida silika, oksida alumunium, oksida magnesium, dan oksida krom (Zulfalina dan Manaf, 2004).

Karakterisasi hasil preparasi material magnetik pasir besi Pantai Lansilowo menunjukkan bahwa masih mengandung oksida pengotor seperti oksida krom, oksida magnesium, oksida silika, dan oksida alumina (Prasdiantika dan Susanto, 2016).

Fahmiati dkk. (2017) melakukan tretment material magnetik pasir besi Pantai Bugel Kulon Progo menggunakan larutan basa yaitu larutan $\mathrm{NaOH}$ pada konsentrasi $4 \mathrm{M}$ dan 8 M. Hasil karakterisasi menunjukkan bahwa treatment pasir besi menggunakan larutan basa dapat meningkatkan kandungan oksida besi $\left(\mathrm{Fe}_{2} \mathrm{O}_{3}\right)$ dan $\mathrm{TiO}_{2}$. Namun treatment tersebut 
tidak dapat menghilangkan oksida pengotor lain yang tidak dapat larut dalam basa.

Wijaya dkk., (2010) melakukan pengujian pengaruh larutan asam yaitu larutan asam sulfat dengan konsentrasi $1 \mathrm{M}, 2 \mathrm{M}$, dan $3 \mathrm{M}$ terhadap kestabilan struktur montmorilonit terpilar pada oksida besi. Penambahan larutan asam sulfat ternyata mampu melarutkan magnesium dan alumunium. Namun penggunaan larutan sulfat dengan konsentrasi yang tinggi dapat mengakibatkan sebagian besi dalam komposit ikut larut. Selain itu, penggunaan larutan asam yang sangat kuat (bervalensi dua) seperti larutan asam sulfat dapat melarutkan sebagian pilar oksida besi.

Oleh karena itu, untuk mendapatkan material magnetik pasir besi dengan kemurnian yang tinggi, material magnetik perlu dicuci atau diaktivasi menggunakan larutan asam (bervalensi satu) seperti $\mathrm{HCl}$ pada konsentrasi rendah untuk menghilangkan oksida-oksida pengotor yang dapat larut dengan asam, dan meminimalisir oksida besi yang larut.

Dalam penelitian ini dilakukan pencucian material magnetik pasir besi Lansilowo menggunakan larutan $\mathrm{HCl} 0,5 \mathrm{M}$, dan mempelajari karakteristik material magnetik pasir besi akibat pencucian larutan $\mathrm{HCl}$ 0,5 M.

Penelitian ini bertujuan untuk memberikan alternatif pemurnian material magnetik pasir besi, menghilangkan oksida pengotor, dan peningkatan kemurnian oksida besi pada material magnetik pasir besi.

\section{Metode}

\section{Alat dan Bahan}

Peralatan preparasi material magentik pasir besi terdiri dari neraca analitik (Meter AE 160), magnet eksternal (Niobium), oven (Fisher Scientific), sonikator (bransonik 3210; $48 \mathrm{KHz} ; 220$ volt), labu Erlenmeyer, gelas ukur, gelas Beaker, labu ukur, lumpang, dan mortar porselen.

Peralatan analisis yang digunakan untuk mengumpulkan data hasil penelitian yaitu X-Ray Fluorescence (XRF) PAnalytical Minipal 4 untuk mengetahui kandungan dan komposisi dari material magnetik pasir besi, Spectrophotometer Fourier Transform
Infrared (FT-IR) dengan merk Shimadzu FTIRPRESTIGE 21 untuk mengidentifikasi gugus fungsional material magnetik pasir besi, X-Ray Difraktometer (XRD) Shimadzu 6000 untuk mengidentifikasi jenis material, ukuran kristal material, dan kristalinitas material magentik pasir besi.

Preparasi material magnetik pasir besi menggunakan bahan-bahan yaitu pasir besi yang diperoleh dari pesisir Pantai Lansilowo Kabupaten Konawe, akuades, dan larutan $\mathrm{HCl}$ 37\% (Merck).

\section{Prosedur Preparasi material magnetik pasir besi}

Pasir besi sebanyak 100 gram dipisahkan menggunakan magnet untuk mendapatkan material yang bersifat magnetik. Material yang tertarik oleh magnet eksternal digerus dan ditimbang (Prasdiantika dan Susanto, 2016). Serbuk pasir besi yang didapatkan kemudian dikarakterisasi menggunakan X-Ray Fluorescence (XRF), X-Ray Difraktometer (XRD), dan spektrofotometer FT-IR.

\section{Pencucian material magnetik pasir besi dengan $\mathrm{H}_{2} \mathrm{O}$}

Sebanyak 30 gram material magnetik pasir besi hasil preparasi dimasukkan ke dalam gelas kimia. Kemudian ditambahkan akuades sebanyak $100 \mathrm{~mL}$. Setelah itu disonikasi sebanyak 3 kali selama 30 menit. Campuran yang diperoleh, lalu dipisahkan menggunakan magnet eksternal.

Endapan yang berwarna hitam diambil, dan larutannya dibuang. Endapan dikeringkan pada suhu $80^{\circ} \mathrm{C}$ sampai kering, digerus, lalu ditimbang (Prasdiantika dan Susanto, 2016). Serbuk yang diperoleh dikarakterisasi dengan X-Ray Fluorescence (XRF), X-Ray Difraktometer (XRD), dan spektrofotometer FT-IR.

\section{Pencucian material magnetik pasir besi dengan $\mathrm{HCl}$}

Sebanyak 10 gram material magnetik hasil pencucian dengan akuades, dicuci menggunakan larutan $\mathrm{HCl}$ 0,5 M sebanyak 10 
$\mathrm{mL}$, disonikasi selama 30 menit, lalu dibilas dengan akuades.

Campuran yang diperoleh, dipisahkan menggunakan magnet eksternal dan diambil endapannya. Endapan tersebut dikeringkan pada suhu $80^{\circ} \mathrm{C}$ sampai kering, digerus, lalu ditimbang, dan disimpan dalam wadah. Serbuk yang diperoleh dikarakterisasi dengan X-Ray Fluorescence (XRF), X-Ray Difraktometer (XRD), dan FT-IR.

\section{HASIL DAN PEMBAHASAN Hasil Preparasi Material Magnetik Pasir Besi}

Material pasir besi diperoleh dari Pantai Lansilowo. Material magnetik pasir besi dapat dipisahkan dari pengotor-pengotornya menggunakan magnet eksternal. Hasil preparasi menunjukkan material magnetik pasir besi Lansilowo didominasi oleh oksida besi magnetit (Prasdiantika dan Susanto, 2016).

\section{Hasil Pencucian Material Magnetik Pasir Besi dengan $\mathrm{H}_{2} \mathrm{O}$}

Material magnetik hasil preparasi dicuci dengan $\mathrm{H}_{2} \mathrm{O}$ untuk menghilangkan atau melarutkan pengotor-pengotor yang dapat larut dengan $\mathrm{H}_{2} \mathrm{O}$. Material magnetik pasir besi Pantai Lansilowo yang didominasi oleh oksida besi magnetit, setelah dicuci menggunakan akuades masih mengandung beberapa oksida lain seperti oksida krom, oksida alumina, dan oksida silika (Prasdiantika dan Susanto, 2016).

\section{Hasil Pencucian Material Magnetik Pasir Besi dengan $\mathrm{HCl}$}

Sebanyak 30 gram material magnetik pasir besi dicuci dengan larutan $\mathrm{HCl}$ 0,5 M $100 \mathrm{~mL}$ untuk menghilangkan oksida-oksida pengotor dan meningkatkan kemurnian oksida besi. Campuran yang masih berada di dalam gelas kimia dipisahkan dengan bantuan magnet eksternal untuk memisahkan partikel yang dapat tertarik oleh magnet dan partikel yang tidak dapat ditarik oleh magnet eksternal.

Material magnetik pasir besi dikeringkan dengan menggunakan oven pada temperatur $80{ }^{\circ} \mathrm{C}$ selama 24 jam, dipisahkan kembali menggunakan magnet ekternal untuk mendapatkan fasa dominan magnetit.

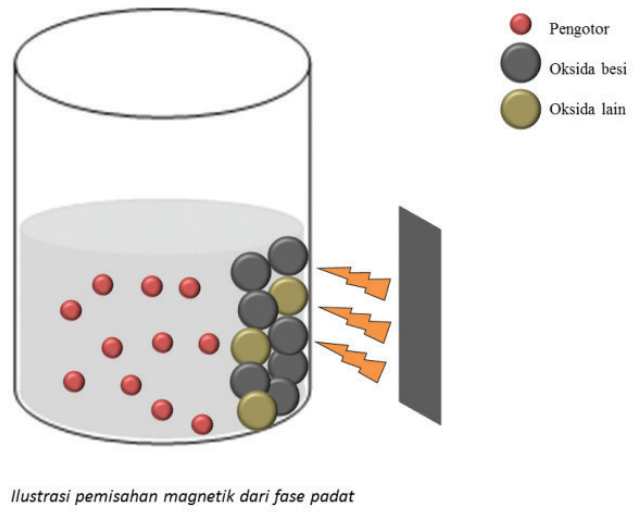

Gambar 1.

Ilustrasi pemisahan material magnetik pada proses pencucian $\mathrm{H}_{2} \mathrm{O}$ dan $\mathrm{HCl} \mathrm{0,5} \mathrm{M}$

Sumber gambar: (dokumen pribadi Penulis)

Hasil Analisis Kandungan Material (Uji X-Ray Fluorescence)

Material magnetik yang telah dipisahkan dengan menggunakan magnet eksternal dikarakterisasi menggunakan X-Ray Fluorescence (XRF) untuk menentukan kandungan dari bahan magnetik pasir besi dan unsur-unsur pengotor yang tidak dapat dipisahkan dengan magnet eksternal.

Pada materialmagnetikyang dicucidengan $\mathrm{H}_{2} \mathrm{O}-\mathrm{HCl}$ 0,5 $\mathrm{M}$ juga dilakukan karakterisasi uji X-Ray Fluorescence (XRF). Karakterisasi tersebut dilakukan untuk mengidentifikasi unsur pengotor yang hilang dan larut setelah proses pencucian dengan $\mathrm{H}_{2} \mathrm{O}-\mathrm{HCl} 0,5 \mathrm{M}$. Hasil karakterisasi X-Ray Fluorescence (XRF) sebelum dan setelah pencucian dengan $\mathrm{H}_{2} \mathrm{O}-\mathrm{HCl} 0,5 \mathrm{M}$ dapat dilihat pada Tabel 1.

Tabel 1

Hasil karakterisasi uji XRF material magnetik pasir besi Lansilowo sebelum dan setelah pencucian

\begin{tabular}{llll}
\hline \multirow{2}{*}{ Unsur } & \multicolumn{3}{c}{ Komposisi (\%) } \\
\cline { 2 - 4 } & \multicolumn{1}{c}{$\mathbf{P B}$} & \multicolumn{1}{c}{ PB-H $_{2} \mathbf{O}$} & PB-HCl 0,5 $\mathbf{~ M}$ \\
\hline $\mathrm{Fe}$ & 46,13 & 48,57 & 51,3 \\
$\mathrm{Cr}$ & 28,08 & 29,02 & 41,5 \\
$\mathrm{Mg}$ & 10,11 & 8,25 & - \\
$\mathrm{Si}$ & 8,20 & 7,68 & 1,50
\end{tabular}




\begin{tabular}{|c|c|c|c|}
\hline \multirow{2}{*}{ Unsur } & \multicolumn{3}{|c|}{ Komposisi (\%) } \\
\hline & PB & $\mathrm{PB}-\mathrm{H}_{2} \mathrm{O}$ & PB-HCl 0,5 M \\
\hline $\mathrm{Al}$ & 4,24 & 2,87 & 1,30 \\
\hline $\operatorname{Pr}$ & 0,45 & 0,42 & - \\
\hline Mn & 0,43 & 0,43 & 1,40 \\
\hline $\mathrm{Ti}$ & 0,42 & 0,42 & 0,57 \\
\hline K & 0,36 & 0,32 & - \\
\hline $\mathrm{Cl}$ & 0,29 & 0,21 & - \\
\hline $\mathrm{Ca}$ & 0,23 & 0,20 & 0,34 \\
\hline $\mathrm{P}$ & 0,22 & 0,18 & - \\
\hline $\mathrm{Zn}$ & 0,22 & 0,22 & 0,33 \\
\hline $\mathrm{Ni}$ & 0,19 & 0,17 & 0,27 \\
\hline$S$ & 0,14 & 0,12 & - \\
\hline Co & 0,13 & 0,13 & - \\
\hline $\mathrm{Ce}$ & 0,13 & 0,13 & - \\
\hline Sn & 0,02 & 0,02 & - \\
\hline
\end{tabular}

${ }^{*} \mathrm{~PB}=$ material magnetik pasir besi

Sumber: Hasil analisis

Berdasarkan Tabel 1 dapat diketahui bahwa material magnetik pasir besi Pantai Lansilowo mengandung unsur-unsur mayor seperti unsur Fe dengan kadar sekitar 46,13\%, unsur $\mathrm{Cr}$ dengan kadar sekitar 28,08\%, Mg dengan kadar sekitar 10,11\%, Si dengan kadar sekitar 8,20\%, Al dengan kadar sekitar 4,24\%, dan unsur minor lainnya.

Berdasarkan hasil karakterisasi XRF tersebut, terlihat bahwa unsur Fe memiliki kadar yang paling tinggi dan mendominasi komposisi material magnetik dari pasir besi Pantai Lansilowo. Kadar Fe yang cukup tinggi tersebut disebabkan oleh beberapa faktor seperti kondisi geografis daerah diperolehnya sampel dan preparasi sampel yang dilakukan dengan menggunakan magnet eksternal (Prasdiantika dan Susanto, 2016).

Pada hasil preparasi material magnetik masih mengandung unsur-unsur $\mathrm{Fe}, \mathrm{Cr}, \mathrm{Mg}$, dan Al dengan kadar lebih dari 4\%. Hal ini dikarenakan unsur-unsur tersebut merupakan unsur-unsur yang bersifat magnetik. Oleh karena itu, ketika material magnetik pasir besi ditarik oleh magnet eksternal, unsurunsur tersebut juga tertarik magnet eksternal. Selain itu, daerah diperolehnya sampel juga merupakan daerah penghasil sumber daya mineral krom dan magnesium. Sehingga material magnetik yang diperoleh masih mengandung unsur $\mathrm{Fe}, \mathrm{Cr}, \mathrm{Mg}$, dan $\mathrm{Al}$ dalam persentase jumlah yang cukup banyak.

Setelah dilakukan pencucian dengan menggunakan akuades, diperoleh persentase komposisi dari unsur Fe meningkat sebanyak $2,44 \%$ menjadi $48,57 \%$. Hal ini dimungkinkan pencucian material magnetik dengan akuades mampu menghilangkan beberapa pengotor yang menyelimuti oksida besi, yang dapat larut dengan akuades.

Pada Tabel 1 tersebut terlihat bahwa beberapa pengotor dari material magnetik sudah hilang atau larut dalam larutan $\mathrm{HCl}$ 0,5 M. Persentase komposisi dari unsur Fe juga menjadi meningkat. Hasil pencucian menggunakan larutan $\mathrm{HCl}$ 0,5 M mampu meningkat komposisi unsur Fe menjadi 51,30\%.

Pada tabel tersebut terlihat bahwa unsurunsur seperti $\mathrm{Mg}$, Pr, K, Cl, P, S, Co, Ce, dan Sn sudah tidak ada lagi pada pencucian material magnetik dengan larutan $\mathrm{HCl}$. Persentase komposisi dari unsur Si dan Al juga mengalami penurunan. Hal ini dikarenakan pencucian material magnetik dengan larutan $\mathrm{HCl} 0,5$ M mampu menghilangkan dan melarutkan beberapa pengotor yang menyelimuti material magnetik.

\section{Hasil Analisis kritalinitas dan ukuran kristal (Uji X-Ray Difraktometer)}

Material magnetik pasir besi hasil pencucian, dikarakterisasi dengan XRD untuk mengetahui pengaruh kristalinitas dan ukuran kristal material magnetik pasir besi sebelum dan setelah pencucian material magnetik pasir besi menggunakan larutan asam klorida. Hasil karakterisasi XRD dari pencucian material magnetik pasir besi dengan larutan asam klorida ditunjukkan dari pada Gambar 2. Karakterisasi XRD dilakukan untuk mendapatkan pola difraksi sinar-X dari material magnetik pasir besi. Proses identifikasi didasarkan pada pencocokan data dengan menggunakan metode searchmatch. Analisa data XRD dilakukan pada rentang $2 \theta$ (dua theta) $10^{\circ}$ sampai dengan $80^{\circ}$. 


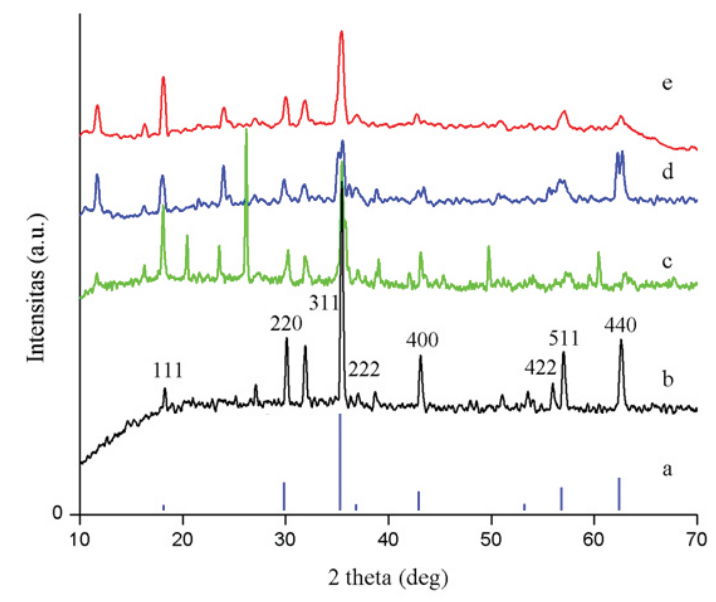

Gambar 2.

Difraktogram (a) JCPDS 01-075-0449, (b) magnetit komersial, (c) material magentik pasir besi tanpa dicuci, (d) material magentik pasir besi dicuci $\mathrm{H}_{2} \mathrm{O}$, dan (e) material magnetik pasir besi dicuci $\mathrm{H}_{2} \mathrm{O}-\mathrm{HCl} 0,5 \mathrm{M}$

Sumber: Hasil analisis

Tinggi puncak dari masing-masing grafik dari sampel pada Gambar 2 menunjukkan banyaknya sinar- $X$ yang terhambur pada bidang $d_{h k l}$ yang sama. Pada Gambar 2 dapat dilihat perbedaan tinggi puncak yang terbentuk dari material magnetik pasir besi tanpa pencucian, material magnetik pasir besi dicuci pencucian dengan $\mathrm{H}_{2} \mathrm{O}$, dan pencucian dengan $\mathrm{H}_{2} \mathrm{O}-\mathrm{HCl}$ 0,5 M. Namun, letak puncakpuncak tertinggi yang terbentuk, semuanya terletak pada sudut $2 \theta$ yang sama yaitu berada pada sudut $35^{\circ}$ dan $43^{\circ}$. Puncak tersebut menunjukkan puncak karakteristik dari oksida besi magnetit.

Berdasarkan Gambar 2 terlihat hasil karakterisasi material magnetik pasir besi Pantai Lansilowo sebelum dan setelah pencucian dengan larutan $\mathrm{HCl}$ 0,5 M menggunakan XRD, tetap menghasilkan oksida besi berupa magnetit yang bersesuaian dengan database JCPDS 01-075-0449 dan magnetit komersial.

Pada difraktogram Gambar 2 terlihat adanya perbedaan intensitas dari material magnetik pasir besi hasil pencucian. Analisis XRD pada gambar tersebut menunjukkan puncak oksida besi magnetit mengalami peningkatan intensitas setelah proses pencucian dengan $\mathrm{H}_{2} \mathrm{O}$ dan pencucian $\mathrm{H}_{2} \mathrm{O}-\mathrm{HCl} \quad 0,5$ M. Pada Gambar 2 terlihat bahwa material magnetik pasir besi yang dicuci dengan menggunakan $\mathrm{H}_{2} \mathrm{O}-\mathrm{HCl}$ 0,5 M menghasilkan intensitas yang lebih tinggi dibandingkan dengan material magnetik pasir besi yang hanya dicuci dengan $\mathrm{H}_{2} \mathrm{O}$.

Intensitas yang rendah pada material magnetik pasir besi yang dicuci dengan $\mathrm{H}_{2} \mathrm{O}$ dimungkinkan karena material magnetik tersebut masih mengandung banyak pengotor yang tidak dapat larut dengan $\mathrm{H}_{2} \mathrm{O}$, yang masih menyelimuti material magnetik.

Pada Gambar 2 terlihat bahwa hasil pencucian material magnetik Pasir besi dengan $\mathrm{H}_{2} \mathrm{O}-\mathrm{HCl}$ 0,5 $\mathrm{M}$ dapat menghilangkan beberapa puncak residu dari material magnetik. Hal tersebut mengindikasikan bahwa beberapa pengotor dari material magnetik sudah hilang. Hal ini bersesuaian dengan Wijaya dkk (2004) bahwa penambahan larutan asam mampu melarutkan beberapa pengotor seperti magnesium dan alumunium.

Puncak-puncak karakteristik dari magnetit yang dihasilkan dari difraktogram material magnetik pasir besi yang dicuci $\mathrm{H}_{2} \mathrm{O}$ dan dicuci $\mathrm{H}_{2} \mathrm{O}-\mathrm{HCl}$ 0,5 M tersaji pada Tabel 2 .

Tabel 2.

Puncak-puncak karakterisasi XRD dari material magnetik Pasir besi

\begin{tabular}{l|l|l}
\hline \multicolumn{3}{|c}{$2 \boldsymbol{\theta}(\mathrm{deg})$} \\
\hline $\begin{array}{c}\text { Magnetit } \\
\text { Komersial }\end{array}$ & $\begin{array}{c}\text { Pasir besi } \\
\text { cuci } \mathrm{H}_{2} \mathrm{O}\end{array}$ & $\begin{array}{c}\text { Pasir besi cuci } \\
\mathbf{H}_{2} \mathrm{O}-\mathrm{HCl}\end{array}$ \\
\hline 18,29 & 18,52 & 18,63 \\
30,13 & 30,33 & 30,53 \\
35,48 & 35,83 & 35,89 \\
43,13 & 43,88 & 43,25 \\
53,52 & 53,93 & 53,43 \\
57,02 & 57,20 & 57,44 \\
62,62 & 62,71 & 63,00 \\
\hline
\end{tabular}

Sumber: Hasil analisis

Pada Tabel 2 terlihat bahwa material magnetik pasir besi yang dicuci $\mathrm{H}_{2} \mathrm{O}$, dan material magnetik yang dicuci $\mathrm{H}_{2} \mathrm{O}-\mathrm{HCl} 0,5$ $\mathrm{M}$ memiliki puncak-puncak karakteristik yang bersesuaian dengan puncak magnetit komersial. 
Pada material magnetik sebelum dan setelah pencucian dengan $\mathrm{H}_{2} \mathrm{O}-\mathrm{HCl} 0,5 \mathrm{M}$, dilakukan perhitungan jarak antar bidang kristal dan parameter kisinya. Sesuai dengan perhitungan yang dilakukan, diperoleh parameter kisi dan jarak antar bidang kristal seperti yang terlihat pada Tabel 3 .

Tabel 3.

Perbandingan Jarak Antar Bidang Kristal dan Parameter Kisi Material Magnetik Hasil Pencucian

\begin{tabular}{lll}
\hline \multicolumn{1}{c}{ Material } & $\mathbf{d}_{\text {hkl }}(\mathbf{n m})$ & \multicolumn{1}{c}{$\mathbf{a}(\mathbf{n m})$} \\
\hline Magnetit Komersial & 0,246 & 0,838 \\
$\mathrm{~PB}$ & 0,242 & 0,825 \\
$\mathrm{~PB}+\mathrm{H}_{2} \mathrm{O}$ & 0,244 & 0,831 \\
$\mathrm{~PB}+\mathrm{H}_{2} \mathrm{O}+\mathrm{HCl}$ & 0,244 & 0,832 \\
\hline
\end{tabular}

${ }^{*} \mathrm{~PB}=$ material magnetik pasir besi Sumber: Hasil analisis

Berdasarkan tabel tersebut terlihat bahwa material magnetik hasil pencucian dengan magnetit komersial memiliki parameter kisi dan jarak antarbidang kristal yang relatif hampir sama.

Material magnetik yang telah dicuci dengan $\mathrm{H}_{2} \mathrm{O}-\mathrm{HCl}$ 0,5 $\mathrm{M}$ dimungkinkan memiliki sifat yang lebih kristalin dari pada sebelum dicuci. Hal ini dapat dilihat pada hasil karakterisasi XRD material magnetik setelah pencucian memiliki FWHM yang lebih kecil daripada sebelum dilakukan pencucian, difraktogram material magnetik mengalami penyempitan puncak setelah dilakukan pencucian, dan dari hasi perhitungan \% kristalinitas. Hasil perhitungan kristalinitas dari material magnetik tanpa pencucian, cuci $\mathrm{H}_{2} \mathrm{O}$, dan cuci $\mathrm{H}_{2} \mathrm{O}-\mathrm{HCl}$ 0,5 M disajikan pada Tabel 4 .

Tabel 4.

Perbandingan Ukuran dan Kristalinitas Material Magnetik Hasil Pencucian

\begin{tabular}{lrl}
\hline \multicolumn{1}{c}{ Material } & Dxrd (nm) & Kristalinitas (\%) \\
\hline $\mathrm{PB}$ & $40,98 \pm 4,16$ & 33,81 \\
$\mathrm{~PB}+\mathrm{H}_{2} \mathrm{O}$ & $23,06 \pm 4,60$ & 47,84 \\
$\mathrm{~PB}+\mathrm{H}_{2} \mathrm{O}+\mathrm{HCl}$ & $37,70 \pm 4,62$ & 53,12 \\
\hline
\end{tabular}

${ }^{*} \mathrm{~PB}=$ material magnetik pasir besi

Sumber: Hasil analisis
Berdasarkan Tabel 4 terlihat kristalinitas (\%) dari masing-masing perlakuan pencucian terhadap material magnetik pasir besi. Berdasarkan tabel tersebut dapat diketahui bahwa pencucian menggunakan $\mathrm{H}_{2} \mathrm{O}-\mathrm{HCl}$ 0,5 M menghasilkan kristalinitas paling tinggi yaitu $53,12 \%$, dan material magnetik pasir besi tanpa pencucian menghasilkan kristalinitas paling rendah yaitu 33,81\%. Hal ini menunjukkan bahwa kristalinitas material magnetik pasir besi mengalami peningkatan setelah dilakukan pencucian dengan $\mathrm{H}_{2} \mathrm{O}-\mathrm{HCl}$ $0,5 \mathrm{M}$. Hal ini dimungkinkan pencucian $\mathrm{H}_{2} \mathrm{O}$ $\mathrm{HCl}$ 0,5 M mampu menghilangkan beberapa pengotor pada material magnetik pasir besi yang dapat larut dengan larutan $\mathrm{HCl}$ 0,5 M.

Pada material magnetik pasir besi juga dilakukan penentuan ukuran kristal dengan menggunakan persamaan Deybe-Scherrer sebagaimana dikemukakan oleh $\mathrm{Wu}$ dkk. (2011). Setelah dilakukan perhitungan, diperoleh ukuran kristal dari material magnetik seperti yang tersaji pada Tabel 3.

Pada tabel tersebut terlihat bahwa material magnetik pasir besi tanpa pencucian memiliki ukuran kristal paling besar yaitu 40,98 \pm 4,16 $\mathrm{nm}$, dan material magnetik yang hanya dicuci dengan $\mathrm{H}_{2} \mathrm{O}$ menghasilkan ukuran kristal yang paling kecil yaitu 23,06 $\pm 4,60 \mathrm{~nm}$. Pencucian material magnetik pasir besi menggunakan $\mathrm{H}_{2} \mathrm{O}-\mathrm{HCl}$ 0,5 M menghasilkan ukuran kristal sebesar yaitu $37,70 \pm 4,62 \mathrm{~nm}$.

Ukuran tersebut ternyata lebih besar dibandingkan ukuran kristal material magnetik pasir besi yang hanya dicuci dengan $\mathrm{H}_{2} \mathrm{O}$ saja. Hal ini dimungkinkan karena partikel-partikel pada material magnetik yang dicuci $\mathrm{H}_{2} \mathrm{O}-\mathrm{HCl}$ 0,5 M mengalami agregasi membentuk agregat. Sehingga menyebabkan ukuran kristal dari material magnetik pasir besinya lebih besar dari material magnetik yang hanya dicuci menggunakan akuades.

Pada kondisi padatan maupun larutan, magnetit rentan mengalami agregasi (Yu dkk., 2002). Agregasi dapat terjadi dikarenanakan adanya tarikan dipolar yang sangat kuat antar partikel dari material magnetik itu sendiri. 


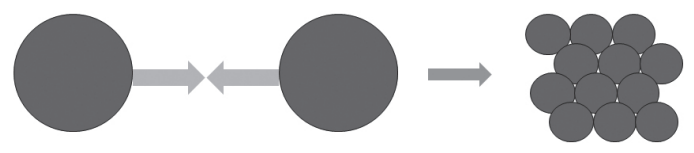

Ilustrasi pembentukan agregat disebabkan oleh gaya kopling antar partikel magnet

Gambar 3.

Ilustrasi terjadinya proses agregasi pada partikel magnetit

Sumber: Prasdiantika dan Susanto (2016)

\section{Hasil Analisis Gugus Fungsional (Uji Fourier Transform Infrared Spectrophotometer)}

Material magnetik pasir besi dikarakterisasi dengan spektofotometer FTIR untuk mengetahui karateristik material magnetik setelah pencucian dengan larutan $\mathrm{HCl}$ 0,5 M. Hasil spektrofotometer FT-IR material magnetik pasir besi sebelum dan sesudah pencucian dengan larutan $\mathrm{HCl}$ 0,5 M disajikan pada Gambar 4.

Berdasarkan Gambar 4, terlihat bahwa spektra FT-IR dari material magnetik pasir besi tanpa pencucian, pencucian dengan $\mathrm{H}_{2} \mathrm{O}$, maupun pencucian $\mathrm{H}_{2} \mathrm{O}-\mathrm{HCl}$ 0,5 $\mathrm{M}$ tidak jauh berbeda. Puncak-puncak serapan karakteristik dari oksida besi magnetit pasir besi masih terlihat setelah proses pencucian.

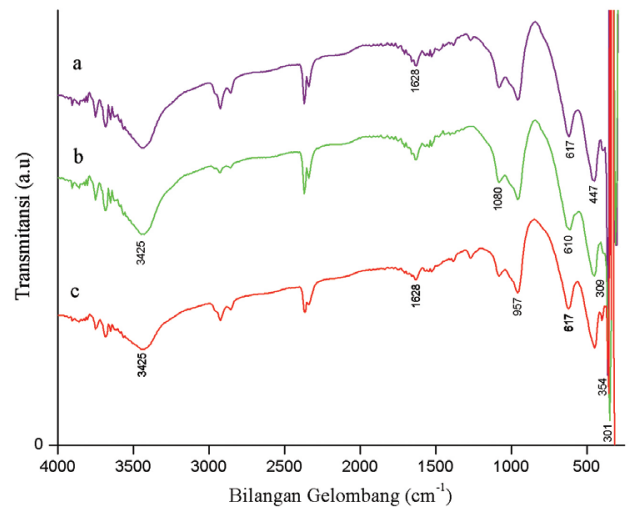

Gambar 4.

Spektra FT-IR (A) Material Magnetik Pasir Besi Sebelum Dicuci, (B) Material Magnetik Pasir Besi Cuci $\mathrm{H}_{2} \mathrm{O}$, dan (C) Material Magnetik Pasir Besi Cuci $\mathrm{H}_{2} \mathrm{O}-\mathrm{Hcl}$ 0,5 M

Sumber: Hasil Analisis
Puncak-puncak serapan karakteristik tersebut diantaranya terdapat vibrasi ulur dari Fe-O magnetit pada bilangan gelombang 610$617 \mathrm{~cm}^{-1}$ (Yamaura dkk., 2004; Jitianu dkk., 2006). Setelah dilakukan pencucian dengan $\mathrm{H}_{2} \mathrm{O}-\mathrm{HCl}$ 0,5 M muncul pita serapan baru pada bilangan gelombang $354 \mathrm{~cm}^{-1}$ yang juga merupakan vibrasi ulur dari Fe-O. Bilangan gelombang $1628 \mathrm{~cm}^{-1}$ yang menunjukkan vibrasi tekuk dari gugus $-\mathrm{OH}$ pada permukaan oksida besi (Fe-OH) atau silanol (Si-OH), sedangkan pada $3425 \mathrm{~cm}^{-1}$ yang menunjukkan adanya vibrasi ulur -OH dari Fe-OH atau Si-OH (Jal dkk., 2004; Petcharoen dan Sirivat, 2012).

Adanya silika pada pencucian material magnetik ini juga masih terlihat pada bilangan gelombang $1080 \mathrm{~cm}^{-1}$ yang merupakan serapan karakteristik untuk vibrasi ulur asimetri Si-O dari gugus siloksan Si-O-Si, pada bilangan gelombang $957 \mathrm{~cm}^{-1}$ yang menunjukkan vibrasi ulur Si-O dari silanol (Si-OH) (Saman dkk., 2014), dan pada bilangan gelombang $447 \mathrm{~cm}^{-1}$ merupakan vibrasi tekuk Si-O dari gugus Si-OSi (Zulkifli dkk., 2013).

Perbandingan puncak-puncak serapan pada material magnetik pasir besi sebelum dan setelah pencucian dengan $\mathrm{H}_{2} \mathrm{O}$ dan larutan $\mathrm{HCl}$ 0,5 $\mathrm{M}$ diperlihatkan pada Tabel 5 .

Tabel 5.

Perbandingan Serapan FT-IR Dari Material Magnetik Pasir Besi Hasil Pencucian

\begin{tabular}{lccc}
\hline & \multicolumn{3}{c}{$\begin{array}{c}\text { Bilangan Gelombang } \\
\text { Karakter Serapan }\end{array}$} \\
\cline { 2 - 5 } & PB & $\begin{array}{c}\text { PB + } \\
\mathbf{H}_{2} \mathbf{O}\end{array}$ & $\begin{array}{c}\text { PB+ HC } \\
\text { + HCl }\end{array}$ \\
\hline $\begin{array}{l}\text { Vibrasi ulur dari } \\
\text { Fe-O }\end{array}$ & 617 & $\begin{array}{l}347, \\
610\end{array}$ & 354,617 \\
$\begin{array}{l}\text { Vibrasi tekuk Si-O } \\
\text { dari Si-O-Si }\end{array}$ & 301, & 309, & 301,447 \\
$\begin{array}{l}\text { Vibrasi ulur Si-O } \\
\text { dari Si-OH }\end{array}$ & 447 & 447 & \\
$\begin{array}{l}\text { Vibrasi ulur Si-O } \\
\text { dari Si-O-Si }\end{array}$ & 957 & 957 & 957 \\
$\begin{array}{l}\text { Vibrasi tekuk O-H } \\
\text { dari FeOH, SiOH }\end{array}$ & 1080 & 1080 & 1080 \\
$\begin{array}{l}\text { Vibrasi ulur O-H dari } \\
\text { Si-OH atau Fe-OH }\end{array}$ & 3425 & 3425 & 3425 \\
\hline
\end{tabular}

Sumber: Hasil analisis 
Berdasarkan tabel tersebut, terlihat ada sedikit pergeseran bilangan gelombang untuk beberapa puncak serapan pada gugus-gugus fungsi utama dari senyawa magnetit. Namun, puncak-puncak tersebut masih dalam range spesiasi vibrasi gugus yang sama, sehingga masih tetap dapat diindentifikasi sebagai serapan gugus fungsi dari material magnetit.

Berdasarkan karakterisasi tersebut, dapat terlihat bahwa pencucian material magnetik dengan menggunakan larutan $\mathrm{HCl}$ 0,5 M tidak mempengaruhi pergeseran puncak spektra secara signifikan. Oksida besi dari material magnetik pasir besi Lansilowo tetap berupa oksida besi magnetit.

Berdasarkan hasil karakaterisasi XRF, FTIR, dan XRD menunjukkan bahwa pencucian material magnetik pasir besi menggunakan larutan $\mathrm{HCl}$ 0,5 M tidak mengubah jenis oksida yang terkandung dalam material, mampu menghilangkan residu atau pengotor yang menyelimuti material, dan meningkatkan persentase kandungan $\mathrm{Fe}$ dalam material magnetik pasir besi.

\section{SIMPULAN}

Pasir besi Lansilowo mengandung oksida besi berupa magnetit. Pencucian material magnetik pasir besi dengan menggunakan larutan $\mathrm{HCl}$ 0,5 $\mathrm{M}$ berhasil menghilangkan unsur-unsur pengotor seperti $\mathrm{Mg}, \mathrm{Pr}, \mathrm{K}, \mathrm{Cl}, \mathrm{P}$, $\mathrm{S}, \mathrm{Co}, \mathrm{Ce}$, dan Sn. Persentase komposisi dari unsur Si dan Al juga mengalami penurunan. Pencucian material magnetik pasir besi dengan menggunakan $\mathrm{H}_{2} \mathrm{O}-\mathrm{HCl}$ 0,5 M mampu meningkatkan persentase komposisi unsur Fe.

Pencucian material magnetik pasir besi menggunakan $\mathrm{H}_{2} \mathrm{O}-\mathrm{HCl}$ 0,5 $\mathrm{M}$ menghasilkan intensitas $\mathrm{XRD}$ yang lebih tinggi dibandingkan material magnetik pasir besi yang hanya dicuci dengan $\mathrm{H}_{2} \mathrm{O}$. Pencucian material magnetik menggunakan larutan $\mathrm{HCl} 0,5 \mathrm{M}$ dapat meningkatkan kristalinitas material magnetik. Pencucian material magnetik dengan $\mathrm{H}_{2} \mathrm{O}$ $\mathrm{HCl}$ 0,5 M menghasilkan ukuran partikel 37,70 $\pm 4,62 \mathrm{~nm}$ dan kristalinitas paling tinggi yaitu sebesar $53,12 \%$.

\section{UCAPAN TERIMAKASIH}

Penulis mengucapkan terima kasih kepada Fahmiati atas bantuan bahan penelitian berupa pasir besi yang diberikan.

\section{DAFTAR PUSTAKA}

Afza, E. (2011). Pembuatan MagnetPermanent Ba-Hexa Ferrite dengan Metode Koopresipitasi dan Karakterisasinya. Skripsi, Universitas Sumatera Utara Medan.

Amal, M. I. (2008). Penambahan Pasir Besi untuk Pembuatan Baja Butir Halus dengan Pemaduan Mekanik dan Pengerolan Panas, Tesis. Pasca Sarjana Fakultas Matematika dan Ilmu Pengetahuan Alam, Universitas Indonesia.

Ansori, C. (2013). Mengoptimalkan Perolehan Mineral Magnetik Pada Proses Separasi Magnetik Pasir Besi Pantai Selatan Kabupaten Kebumen Jawa Tengah. Jurnal Teknologi Mineral dan Batubara, 9(3):145-156.

Cornell, R. M. and Schwertmann, U. (2003) The Iron Oxides : Structure, Properties, Reaction, Occurences and Uses. 2nd Ed, Weinheim: Willey-VCH GmbH and Co. KGaA.

Fahmiati, Nuryono, N., and Suyanta, S. (2017). Characteristics of Iron Sand Magnetic Material from Bugel Beach, Kulon Progo, Yogyakarta. IOP Conference Series: Materials Science and Engineering, 172:12020. DOI: 10.1088/1757-899X/172/1/012020.

Jal, P. K. K., Sudarshan, M., Saha, A., Patel, S., and Mishra, B. K. K. (2004). Synthesis and Characterization of Nanosilica Prepared by Precipitation Method. Colloids and Surfaces A: Physicochemical and Engineering Aspects, Elsevier, 240(1):173-178. DOI: 10.1016/j.colsurfa.2004.03.021.

Jitianu, A., Raileanu, M., Crisan, M., Predoi, M., Zaharescu, D., Jitianu, L., and Stanciu, M. (2006). Fe3O4-SiO2 
Nanocomposites Obtained via Alkoxide and Colloidal Route. Journal of Sol-Gel Science and Technology, 40(2-3):317-323.

Komatina, M. and Gudenau, H. W. (2004). The Sticking Problem During Direct Reduction of Fine Iron Ore in The Fluidized Bed. Metalurgija, 10(4):309_ 328.

Kumari, N., Ari, V., Konar, J., and Bhagat, R. P. (2010). Beneficiation Of Iron Ore Slimes from Karnataka Through Dispersion And Selective Flocculation.in Proceedings of the XI International Seminar on Mineral Processing Technology: 564-571.

Lutfi (2012). Penggunaan Pasir Besi Sebagai Pengganti Semen Terhadap Kuat Tekan Dan Kuat Tarik Belah Beton. Media Bina Ilmiah Mataram, 6(2):2428.

Mufit, F., Amir, H., Fadhilah, F., and Bijaksana, S. (2013). Kaitan Sifat Magnetik Dengan Tingkat Kehitaman (Darkness) Pasir Besi Di Pantai Masang Sumatera Barat. Eksakta, 2(14):70-75.

Pari, G. (2000). Pembuatan Arang Aktif Dari Batubara. Jurnal Penelitian Hasil Hutan, 17(4):220-230.

Petcharoen, K. and Sirivat, A. (2012). Synthesis and Characterization of Magnetite Nanoparticles via the Chemical Co-Precipitation Method. Materials Science and Engineering: $B$, 177(5):421-427. DOI: $10.1016 / \mathrm{j}$. mseb.2012.01.003.

Prasdiantika, R. and Susanto, S. (2016). Preparasi dan Penentuan Jenis Oksida Besi Pada Material Magnetik Pasir Besi Lansilowo. Jurnal Teknosains, Universitas Gadjah Mada, 6(1):7-15. DOI: 10.22146/ teknosains.11385.

Rahmawati, R. and Handayani, N. (2013). Handayani. 2013. Fabrikasi Ferrogel Berbahan Dasar Nanopartikel
Magnetit $\left(\mathrm{Fe}_{3} \mathrm{O}_{4}\right)$ Dari Hasil Sintesis Pasir Besi Pantai Utara Jawa Dan Sifat Magneto-Elastisitasnya. Jurnal Neutrino, 5(2):95-104.

Saman, N., Johari, K., and Mat, H. (2014). Adsorption Characteristics of SulfurFunctionalized Silica Microspheres with Respect to the Removal of $\mathrm{Hg}$ (II) from Aqueous Solutions. Industrial \& Engineering Chemistry Research, American Chemical Society,53(3):1225-1233. DOI: 10.1021/ie402824r.

Setiawati, L. D., Rahman, T. P., Nugroho, D. W., Nofrizal, N., Ikono, R., Suryandaru, S., Yuswono, Y., Siswanto, S., and Rochman, N. T. (2013). Ekstraksi Titanium Dioksida (TiO2) Dari Pasir Besi Dengan Metode Hidrometalurgi.in Prosiding Semirata FMIPA Universitas Lampung: 465-468.

Wijaya, K., Sugiharto, E., Mudasir, M., Tahir, I., and Liawati, I. (2010). Synthesis Of Iron Oxide-Montmorillonite Composite And Study Of Its Structural Stability Againts Sulfuric Acid. Indonesian Journal of Chemistry, 4. DOI: 10.22146/ijc.21871.

Wu, S., Sun, A., Zhai, F., Wang, J., Xu, W., Zhang, Q., and Volinsky, A. A. (2011). $\mathrm{Fe} 3 \mathrm{O} 4$ Magnetic Nanoparticles Synthesis from Tailings by Ultrasonic Chemical Co-Precipitation. Materials Letters, $\quad 65(12): 1882-1884 . \quad$ DOI: 10.1016/j.matlet.2011.03.065.

Yamaura, M., Camilo, R. L., Sampaio, L. C., Macêdo, M. A., Nakamura, M., and Toma, H. E. (2004). Preparation and Characterization of (3-Aminopropyl)TriethoxysilaneCoated Magnetite Nanoparticles. Journal of Magnetism and Magnetic Materials, 279(2):210-217. DOI: 10.1016/j.jmmm.2004.01.094.

Yu, L., Yin, Y., Mayers, B., and Xia, Y. (2002). Modifying the Surface Properties 
of Superparamagnetic Iron Oxide Nanoparticles through A Sol-Gel Approach. Nano Letters, 2:183-186. DOI: 10.1021/nl015681q.

Yulianto, A. (2007). Fasa Oksida Besi Untuk Sintesis Serbuk Magnet Ferit. Jurnal Sains Materi Indonesia, 8(3):39-41.

Zulfalina, Z. and Manaf, A. (2004). Identifikasi Senyawa Mineral Dan
Ekstraksi Titanium Dioksida Dari Pasir Mineral. Jurnal Sains Materi Indonesia, 5(2):46-50.

Zulkifli, N. S. C., Ab Rahman, I., Mohamad, D., and Husein, A. (2013). A Green Sol-Gel Route for the Synthesis of Structurally Controlled Silica Particles from Rice Husk for Dental Composite Filler. Ceramics International, 39(4):4559-4567. DOI: 10.1016/j.ceramint.2012.11.052. 